\title{
THE POSSIBILITY OF CONTAMINATION OF WATER-SOIL ENVIRONMENT AS A RESULT OF THE USE OF PIG SLURRY
}

\author{
MOŻLIWOŚĆ ZANIECZYSZCZENIA ŚRODOWISKA WODNO-GLEBOWEGO \\ NA SKUTEK STOSOWANIA GNOJOWICY ŚWIŃSKIEJ
}

\begin{abstract}
Pig slurry is a heterogeneous mixture of faeces, urine, undigested remains of feed items and water used for flushing of animal excrement and to maintain the proper hygiene of livestock housing. It is formed on farms which use the non-bedding system of pig breeding i.e. animals are kept on the partially or fully slatted floors. According to the Polish law pig slurry is defined as a liquid natural fertilizer intended for agricultural use. The storage and application of pig slurry on arable land affect the surroundings and may create a number of serious risks related to, among others, the pollution of water-soil environment with biogenic elements, heavy metals, pathogens and pharmaceuticals. The article presents the reasons for the occurrence of excessive amounts of nitrogen, phosphorus, copper, zinc and antibiotics in pig slurry. The possibility of microbial and pharmaceutical contamination of water, soil and plants as well as their pollution with biogens and heavy metals as a result of improper storage and excessive spreading of pig slurry have been characterized. Moreover, methods of preventing the above-mentioned threats with reference to Polish and EU legal acts have been discussed.
\end{abstract}

Keywords: pig slurry, biogenic elements, heavy metals, pathogenic microorganisms, antibiotics

\section{Introduction}

Pig farming is of great economic importance because pork holds a dominant position, apart from poultry, in global meat production and consumption [1]. A high demand for pork contributes to the intensification of pig production. In large-scale breeding farms mainly non-bedding system of pig farming (animals are kept on the partially or fully slatted floors) is used which generates the formation of large quantities of slurry being a heterogeneous mixture of solid and liquid animal excrement (approximately $40 \%$ faeces and $60 \%$ urine), uneaten feed particles and water used for hygiene and cleaning purposes in pigsty [2-4]. In general, pig slurry is characterized by high degree of hydration, high chemical and biochemical oxygen demand (COD and BOD) and high content of fertilizer macronutrients

\footnotetext{
${ }^{1}$ Faculty of Chemical Engineering and Technology, Cracow University of Technology, ul. Warszawska 24, 31-155 Kraków, Poland, phone +48 126282640

${ }^{2}$ Mineral and Energy Economy Research Institute, Polish Academy of Sciences, ul. J. Wybickiego 7 , 31-261 Kraków, Poland

*Corresponding author: martamarszalek@indy.chemia.pk.edu.pl
} 
(nitrogen, phosphorus, potassium). Pig slurry is also rich in trace elements: iron, zinc and copper and its reaction is usually slightly alkaline [3-5]. The physicochemical characterization of pig slurry according to various research reports is presented in Table 1. The slurry microflora includes bacteria, fungi, viruses and gastrointestinal parasites. Bacteria of the Enterobacteriaceae family, the Streptococcus genus, coliforms and fecal streptococci are predominant. As far as pathogenic microorganisms are concerned, the bacilli of the Salmonella genus, porcine circovirus, porcine parvovirus, porcine reproductive and respiratory syndrome virus as well as eggs and oocysts of the parasites of Ascaris and Trichuris genera occur most frequently [3, 4, 6]. Moreover, slurry may contain antibiotics and other medical preparations which are used therapeutically and prophylactically in pig breeding $[4,7]$.

Basic characteristics of pig slurry according to various literature data [8-16]

Table 1

\begin{tabular}{|c|c|c|c|c|c|c|c|c|c|}
\hline \multirow{2}{*}{ Parameter } & \multicolumn{9}{|c|}{ Reference } \\
\hline & [8] & [9] & {$[10]$} & [11] & [12] & [13] & [14] & [15] & [16] \\
\hline $\mathrm{pH}[-]$ & 7.43 & 7.73 & 6.58 & 5.98 & 7.03 & 7.20 & 7.40 & 7.52 & 6.75 \\
\hline $\begin{array}{c}\text { Conductivity } \\
{[\mathrm{mS} / \mathrm{cm}]}\end{array}$ & 17.9 & 10.2 & 27.9 & 18.8 & - & 9.9 & 16.7 & 21.8 & - \\
\hline $\begin{array}{c}\text { Dry matter } \\
{[\%]}\end{array}$ & - & - & 7.26 & 4.20 & 5.08 & - & - & - & 8.52 \\
\hline $\begin{array}{c}\mathrm{COD} \\
{\left[\mathrm{mg} / \mathrm{dm}^{3}\right]}\end{array}$ & 31600 & 11536 & - & 38000 & 17206 & 17200 & 19119 & - & - \\
\hline $\begin{array}{c}\text { BOD } \\
{\left[\mathrm{mg} / \mathrm{dm}^{3}\right]}\end{array}$ & 14200 & 886 & - & - & 7603 & - & 4780 & - & - \\
\hline $\mathrm{N}\left[\mathrm{mg} / \mathrm{dm}^{3}\right]$ & 2580 & - & 6635 & 2550 & 2621 & - & - & 4790 & 3550 \\
\hline $\mathrm{P}\left[\mathrm{mg} / \mathrm{dm}^{3}\right]$ & 760 & 449 & 1652 & - & 30.64 & 384 & 429 & 860 & 1310 \\
\hline $\mathrm{K}\left[\mathrm{mg} / \mathrm{dm}^{3}\right]$ & 2260 & - & - & - & 916 & - & - & 1660 & 1440 \\
\hline $\mathrm{Cu}\left[\mathrm{mg} / \mathrm{dm}^{3}\right]$ & - & - & - & - & 0.01 & 5.50 & 7.00 & 12.70 & - \\
\hline $\mathrm{Zn}\left[\mathrm{mg} / \mathrm{dm}^{3}\right]$ & - & - & - & - & 2.70 & 26.3 & 45.1 & 109.9 & - \\
\hline
\end{tabular}

According to the Polish legislation [17] slurry is a natural fertilizer intended for agricultural use and therefore the most reasonable way of its management should be its application to fertilize grassland and crop plantations. Unfortunately, in areas where intensive farming of pigs with the use of non-bedding method is run, problems with proper management of large amounts of pig slurry occur, since its production exceeds the acreage of cultivated land on which the slurry can be spread [18]. It should be pointed out that the slurry can't be disposed during winter period [19] and its annual dose per hectare of agricultural land can't contain more than $170 \mathrm{~kg}$ of nitrogen [17, 20]. Therefore, pig producers decide to sell and transport the slurry to distant fields, which is unprofitable, or to spill it in doses exceeding legal limits [2]. The use of excessive quantities of pig slurry poses a risk of soil contamination with biogenic elements [18, 21], heavy metals [22], pharmaceuticals $[4,23]$ and pathogenic microorganisms $[4,24]$ that can penetrate into the groundwater and surface waters threating the health of humans and animals [21]. In addition, nutrient elements, especially phosphorus, which reach water courses and reservoirs contribute to their eutrophication and, consequently, to the ecological disequilibrium of aquatic ecosystems $[18,25,26]$. Improper and too heavy fertilization with slurry may also result in the deterioration of the soil properties, the decrease in crop yield [21], the contamination of edible parts of plants with pathogens [24] or the accumulation of 
heavy metals in their tissues [22]. It should also be noted that pig slurry must be collected and stored in tanks with a sufficiently large capacity until it is taken away to the fields $[17,20,27]$, which generates costs and could significantly affect the environment. Slurry tanks should be tight to prevent slurry from being released into the environment $[17,27]$, nevertheless, inappropriate storage of pig slurry or the occurrence of tank failure may lead to the pollution of soil and water due to the slurry leaking or overflowing [21, 25].

\section{Emission of nitrogen and phosphorus into the soil, groundwater and surface waters}

Nitrogen is one of the elements of great biological importance, since it is a component of many biomolecules, such as amino acids, proteins, nucleotides or nucleic acids. It is provided to animals with protein which is an essential building material of cells. Pigs use nitrogen from food to a limited extent, excreting it with faeces wherein the quantity of nitrogen taken from fodder is determined by the type and bioavailability of amino acids contained in the protein. In general, pigs' organisms absorb from 20 to $50 \%$ of the nitrogen contained in commonly used compound feeds. Nitrogen excretion in faeces is increased in farrowing sows and when a feed ration contains too much crude protein in relation to the needs of animals, or when the protein is of a low biological value [26, 28].

Phosphorus is one of the most important elements responsible for the proper functioning of a pig's organism. It constitutes a building material of tissues and bones and is a part of many organic compounds (nucleic acids, phospholipids, ATP). In the feeding of pigs the phosphorus source are primarily feed phosphates and feed based on plant components in which phosphorus may be in the form of poorly assimilable phytates (phytic phosphorus is typically from 50 to even $85 \%$ of total phosphorus) largely unavailable to pigs, which are excreted in faeces [29-31].

In order to intensify the production of pigs, breeders often give animals the food containing excessive for their needs amounts of nitrogen and phosphorus. Meanwhile, any excess of nutrients taken with the fodder over the animals' requirements is fully excreted in faeces and urine, which leads to a higher content of these elements in the slurry and, consequently, to increased emissions of nitrogen and phosphorus into the environment $[26,29,30]$.

Excrement in the form of slurry is a valuable natural fertilizer, but its inappropriate storage and use in crop fields result in the contamination of ecosystems with biogenic compounds [32]. The pollution of soil, surface waters and groundwater with nitrates and phosphates may occur through the direct infiltration of slurry into the environment due to its leak or overflowing from a tank and during improperly performed transportation as well as a result of too heavy or long-lasting fertilization of agricultural land with the slurry $[21,25]$.

The runoff of nutrients into the groundwater and surface waters occurs also when heavy rain falls just after the application of slurry on the soil, and when fertilizer components are immediately eluted into watercourses before being absorbed by the soil $[25,33]$. Nitrogen unused by plants may also get into the waters due to leaching (nitrates are relatively easily washed out from the soil as they are not sorbed by the soil and always occur in a soluble form), while phosphorus - as a result of soil erosion. Nitrate leaching is much higher in winter (the lack of nutrients uptake by plants, more intensive leaching of 
biogens from the soil by rain water), on sandy soils or soils without the ground cover $[25,33]$.

Nitrogen compounds present in groundwater affect the quality of drinking water and their high concentration is disadvantageous to both humans and animals. In humans, ingestion of excess nitrate in drinking water can cause methemoglobinemia in infants (conversion of hemoglobin to methemoglobin, which depletes oxygen levels in the blood); gastric problems due to the formations of nitrosamines; increase in stomach cancer; hypertrophy of the thyroid gland; hypertension; problems associated with pregnancy (spontaneous abortion, fetal deaths, prematurity, intrauterine growth retardation, low birth weight, congenital malformations) [34-36]. In livestock, cattle are more susceptible to nitrate poisoning than other animal species (pigs or horses) due to the reduction of nitrates to nitrites in their digestive tract $[37,38]$.

In turn, excessive amounts of nitrogen and phosphorus compounds present in surface waters contribute to the eutrophication of water courses and reservoirs as well as water blooms, thereby lowering their suitability for recreational purposes (the deterioration of quality water, shallowing of reservoirs) and disturbing the proper functioning of aquatic ecosystems (extinction of aerobic organisms, massive growth of anaerobic microorganisms, inhibition of oxidative decomposition of organic matter) $[25,26,39]$.

The problem of reducing the emission of biogenic elements into the environment can be solved in various ways. The first step is to reduce the amounts of nitrogen and phosphorus excreted in faeces, which can be achieved through appropriate and adapted to the needs of individual animals balance of nutrients in the feed. The feeding of pigs is based on plant fodder of varying abundance and availability of phosphorus. The fact that pigs cannot use the phosphorous bound in the form of phytate compounds is due to another fact that monogastric animals are unable to produce the phytase enzyme which catalyzes the breakdown of phytates on their own, so that the phosphorus could be resorbed. The application of phytase additive in the feeding of pigs increases the availability of phosphorus, which in turn limits or eliminates the need for supplementing feed with phosphorus of mineral origin. Such an activity significantly reduces the amount of phosphorus in faeces (up to $50 \%$ ) [26, 28, 29, 40-42]. The excretion of nitrogen can be reduced by lowering the level of crude protein in the feed, improving the quality of protein consumed by animals, that is the content and availability of exogenous amino acids, especially lysine, as well as adding phytase to the feed, which results in better digestion and use of amino acids [26, 28, 39-42]. Literature data [26, 28, 29, 39] indicate that application of low protein diet with amino acids supplementation effectively reduces nitrogen excretion without any negative effects on the growth performance of pigs. Moreover, a reduction in odor emissions from slurry was observed [28, 39].

Numerous Polish [17, 19, 43] and EU [20] acts of law prevent the emissions of nitrogen and phosphorus into the soil, groundwater and surface waters. The superior document for the countries of the European Union is the Council Directive 91/676/EEC of 12 December 1991 concerning the protection of waters against pollution caused by nitrates from agricultural sources (so-called the Nitrates Directive) [20]. The Member States were ordered to establish a code of good agricultural practice for farmers to respect on a voluntary basis and which should include provisions for proper storage and application of livestock manure, as well as for ensuring adequate capacity and construction of storage vessels for animal excreta [20]. Other key legal acts which regulate the storage and usage of slurry are: the Act on fertilizers and fertilization of 10 July 2007 [17] and the Public Notice 
of Minister of Agriculture and Rural Development of 17 February 2014 on consolidated text of the Regulation of the Minister of Agriculture and Rural Development on the detailed method of fertilizers application and conducting training regarding their use [19], as well as the Public Notice of Minister of Agriculture and Rural Development of 1 August 2013 on consolidated text of the Regulation of the Minister of Agriculture and Food Economy on the technical conditions for agricultural facilities and their location [43]. According to the above-mentioned legal acts $[17,19,20,43]$ and the Set of recommendations for good agricultural practice [27] slurry must be stored in hermetic and closed tanks of a sufficiently large capacity (enabling to collect at least 6-month production of this fertilizer). Natural fertilizers, including slurry, can be used in the period from 1 March to 30 November [19, 27]; however, the maximum dose of natural fertilizer applied in a year must not exceed $170 \mathrm{~kg}$ of nitrogen in a pure ingredient per 1 ha of agricultural land [17, 20,27]. The slurry can be applied on arable land at a distance of at least $10 \mathrm{~m}$ from the banks of watercourses, lakes and water reservoirs of an area of up to 50 ha and when the groundwater level is below $1.2 \mathrm{~m}$, whereas it is forbidden to use the slurry on soils flooded with water, covered with snow, frozen to the depth of $30 \mathrm{~cm}$ and during rain; on soils without the vegetation cover, located on hillsides with a slope greater than $10 \%$; and during the growing season of plants intended for direct human consumption [17, 19, 27].

An action which prevents the loss of biogenic elements as a result of runoff, erosion, or volatilization and which allows to retain the largest part of fertilizer ingredients for plants is the immediate covering of the spread slurry with soil [25, 44]. In accordance with guidelines of the Public Notice of Minister of Agriculture and Rural Development of 17 February 2014 [19] the slurry should be covered or mixed with the soil no later than the day following its application.

An effective way to reduce nutrient losses from arable land in the autumn and winter period is using short-term grassland or intercrop plants in crop rotation since the longer the soil is covered with vegetation the lesser the nitrate leaching is. Intercrops, apart from limiting the nitrate leaching, can also take in phosphorus, increase the amount of organic matter in the soil and improve its structure [44].

\section{Contamination of soil, water and plants with heavy metals}

Pig slurry, apart from macronutrients (nitrogen, phosphorus and potassium), also contains microelements, such as heavy metals. Heavy metals include both elements essential for the proper functioning of living organisms, such as iron, copper, zinc, manganese and others, and metals unnecessary for the proper functioning of organisms, simply disturbing the biological processes, such as cadmium, mercury and lead [25, 45].

The content of microelements as well as heavy metals in pigs' excreta depends on a diet as they are added to compound feeds, mainly in the form of oxides and salts. Copper and zinc are very important trace elements fulfilling many metabolic functions in animal organisms and, at the same time, raising the greatest fears associated with the risk of environmental contamination [42, 45, 46]. Since copper and zinc are classified as heavy metals, in January 2004 the European Commission introduced the regulation (the Commission Regulation (EC) No 1334/2003 of 25 July 2003) [47] limiting the permissible amount of copper and zinc in fodder for different animal species. In the case of pigs the acceptable limit values for zinc content were reduced from $250 \mathrm{mg}$ to $150 \mathrm{mg}$ per $\mathrm{kg}$ of the complete feedstuff while the maximum level of copper for piglets of up to twelve weeks 
was reduced from $175 \mathrm{mg}$ to $170 \mathrm{mg}$ per $\mathrm{kg}$ of the complete feedstuff and for other pigs from $35 \mathrm{mg}$ to $25 \mathrm{mg}$ of copper per $\mathrm{kg}$ of the complete feedstuff [47].

The Commission Regulation (EC) No 1334/2003 [47] also determined that the allowable content of copper per kg of the complete feedstuff for pigs of over twelve weeks is $25 \mathrm{mg}$; the previous Regulation of the European Commission (the Commission Regulation (EC) No 639/1999 of 25 March 1999) [48] allowed for the use of $175 \mathrm{mg}$ of Cu per $\mathrm{kg}$ of the complete feedstuff for pigs of up to sixteen weeks. The reason for such a decision was the necessity to reduce the share of zinc and copper in excrement (pigs excrete about $72-80 \%$ of $\mathrm{Cu}$ and about $92-96 \%$ of $\mathrm{Zn}$ taken in with fodder) because many farmers in the European Union applied copper and zinc in fattening pigs in excess due to the fact that copper functions as a growth promoter while zinc has an antibacterial and antidiarrheal effect [33, 42, 46].

Literature data concerning the risk of contamination of soil, water and plants with heavy metals as a result of the agricultural use of pig slurry are ambiguous. Many research authors [49-51] emphasize that pig slurry applied on arable fields in a rational way is a safe fertilizer, and the amount of heavy metals that it contains including copper and zinc does not pose a threat to ecosystems. Moreover, even the long-term agricultural use of pig slurry at the recommended doses (with respect to the maximum permissible dose of nitrogen) does not result in exceeding the permissible and determined by law contents of these elements in the soil [49-51]. Certain literature reports [22, 25, 49, 52, 53] indicate that the source of elevated concentrations of copper and zinc in agricultural soils is not pig slurry but the deposition of pollutants from the atmosphere, mineral fertilizers, especially phosphate ones, plant protection products, and compost from municipal and industrial waste as well as from the plants obtained in areas with high contamination by industrial or automotive dusts.

Some of the research authors $[22,42,46,50,54,55]$ pay attention to the fact that the accumulation of heavy metals in the soil, especially in the topsoil $(0-20 \mathrm{~cm})$ and the increased concentration of $\mathrm{Cu}$ in the soil solution at depth may occur as a result of intensive and long-term fertilization with pig slurry. Mantovi et al. [22] noted an increase in zinc and copper content in the soil samples with an increasing dose of slurry. An excessive concentration of heavy metals in the soil can be a source of groundwater and plants contamination, and in consequence these elements can be incorporated into the food chain. However, it should be emphasized that the mere presence of heavy metals in the environment does not yet prove their harmfulness; their bioavailability which depends on genetic properties of plants as well as the amount and chemical form of a metal in the soil is crucial. Copper is usually present in the soil in poorly assimilable forms, although due to changes in the soil environment (e.g. reaction reduction, lowering the organic matter content, the change in water-air relations) it may become more available for plants. In spite of the fact that copper is a little-mobile microelement, the depletion of soil in copper proceeds relatively quickly. Zinc just like copper is a little-mobile element in the soil, and the process of soil depletion in zinc is slow. The uptake of zinc by plants is limited in organic and heavier mineral soils as well as in the case of very high phosphorus content in soil, while an acid reaction of the soil enhances the availability of zinc by plants [22, 55-57]. Despite the increase in the content of heavy metals in the soil, sometimes in concentrations being the environmental burden, the accumulation of heavy metals in edible tissues of plants growing on these soils has not been observed [22, 42, 58]. Mantovi et al. [22] found that the content of copper and zinc in edible tissues of maize, sugar beet and lucerne grown on the soil fertilized with pig and calf slurry was relatively low, below the 
level considered to be toxic for animals and showed no clear correlation with the intensity of slurry application. Similar conclusions were drawn by Berenguer et al. [58] analyzing the content of copper and zinc in maize grains and its other organs.

Research on leaching of heavy metals from soil fertilized with pig slurry into groundwater and surface waters was carried out, among others, by Martinez and Peu [50], Legros et al. [54] and L'Herroux et al. [56]. All of the research groups stated that zinc and copper were leached to groundwater and surface waters in to a very small extent $[50,54$, 56]. However, a relatively high concentration of manganese and cobalt (compared to the content of these elements in the slurry) in groundwater was observed by L'Herroux et al. [56].

An effective way to minimize the hazard of environmental contamination with heavy metals, especially copper and zinc due to the fertilizing usage of pig slurry is to reduce the concentration of these elements in the slurry. This can be achieved through limiting the introduction of copper and zinc with food as well as increasing their bioavailability for pigs as a result of incorporating of microbial phytase or amino acid chelates (e.g. zinc glycinate which is characterized by almost $100 \%$ bioavailability) into the animals diet $[28,42,45]$.

\section{Microbiological contamination of the environment}

Pig slurry is characterized by rich microbiological composition and it may contain microorganisms excreted by animals together with faeces, urine, milk, blood, purulent exudate, nasal and throat discharges, as well as discharge from vaginal tracts and amniotic fluid [4]. Most of the microorganisms involved in the slurry microflora are saprophytic intestinal bacteria, among which the most common are coliforms, however, pathogens may also be present in the slurry - primarily bacteria of the genus Salmonella (mostly S. Typhimurium, S. Enteritidis and S. Derby), Listeria, Brucella, Brachyspira, Leptospira, Campylobacter, Mycobacterium as well as Erysipelothrix rhusiopathiae or verotoxic and enteropathogenic strains of Escherichia coli and also viruses (classical swine fever virus, African swine fever virus, Aujeszky's disease virus called also pseudorabies virus, foot-and-mouth disease virus, porcine parvovirus, porcine circovirus, porcine adenovirus and porcine reproductive and respiratory syndrome virus) $[6,59,60]$. In addition to bacteria and viruses the slurry may also contain fungi and parasites of the gastrointestinal tract of pigs (mainly Ascaris suum, Trichuris suis, Strongyloides ransomi, Oesophagostomum denatum, Isospora suis), their eggs and oocysts [59-61]. The source of pathogenic microorganisms in pig slurry can be sick animals, individuals during an incubation period of the disease or asymptomatic carriers [59]. In slurry derived from healthy pigs there is a natural intestinal microflora characterized by moderate or negligible virulence, while the slurry from animals including sick individuals or carriers may be a significant source of zoonoses and epizootic diseases [24, 62]. This is encouraged by physicochemical properties of the slurry which is inherently not subject to the process of thermal sanitizing and which, in the absence of its conditioning, can cause microbial contamination of soils, groundwater and surface waters as well as plants posing a threat to human and animal health [4].

Pathogenic microorganisms are able to survive in slurry for a relatively long time (Tables 2 and 3) and, under favorable conditions, can rapidly multiply in the early stages of storage. The activity period of bacteria, viruses, fungi and parasites in the stored pig slurry varies strongly and depends on the physicochemical properties of the slurry (reaction, dry matter content, organic matter content, nutrient content), the type and initial quantity of 
microorganisms and ambient temperature (the lower the temperature, the longer the viability) [4, 6, 24, 59]. It should be mentioned that data concerning the survival of pathogens in pig slurry on-farm conditions, where urine and feces are being added on a continual basis, are limited and most of the information derives from laboratory studies [63]. Bacteria in pig slurry can survive for many days (Table 2), according to Olszewska and Skowron [64] bacilli of Salmonella Typhimurium are able to survive in the slurry stored in laboratory conditions at $4{ }^{\circ} \mathrm{C}$ for about 75 days while at $20{ }^{\circ} \mathrm{C}$ their survival time is shorter and amounts 30 days. However, Kachnic et al. [65] noted that Salmonella Typhimurium survived in the pig slurry (stored in closed plastic containers) for less than 115 days at $4{ }^{\circ} \mathrm{C}$ and less than 90 days at $20{ }^{\circ} \mathrm{C}$ and $42{ }^{\circ} \mathrm{C}$. Ajariyakhajorn et al. [66] observed that Salmonella Anatum survived in the pig slurry, the $\mathrm{pH}$ of which was equal to 7.0, for 56 days at $4{ }^{\circ} \mathrm{C}$. Cote et al. [67] found that the maximal persistence of bacteria of the genus Salmonella in pig slurry stored under typical conditions for commercial pig production in Quebec was 88 days.

Survival of selected pathogenic bacteria of pigs in slurry and soil $[59,70]$

\begin{tabular}{|c|c|c|}
\hline Pathogenic bacteria & Survival in slurry & Survival in soil \\
\hline Escherichia coli & $7-28$ days & $8-104$ days \\
\hline Salmonella spp. & $1-42$ days & $16-131$ days \\
\hline Erysipelothrix rhusiopathiae & no data & 35 days \\
\hline Streptococcus suis & $3-104$ days & no data \\
\hline Clostridium perfringens & several weeks & 10 days \\
\hline Brachyspira hyodysenteriae & $7-112$ days & 119 days \\
\hline Brachyspira pilosicoli & 210 days & less than 20 days \\
\hline Pasteurella multocida & $3-6$ days & \\
\hline
\end{tabular}

The pathogenicity of viruses can vary widely (Table 3); in fresh slurry, in open tanks, the foot-and-mouth disease virus can live up to 45 days, in turn, the Aujeszky's disease virus in summer can live up to 3 weeks, while in winter up to 15 weeks [59]. According to Botner and Belsham [68] the survivability of the foot-and-mouth disease virus in the pig slurry stored under anaerobic conditions at $5{ }^{\circ} \mathrm{C}$ is over 14 weeks, the classical swine fever virus over 6 weeks, while porcine parvovirus over 40 weeks. Ajariyakhajorn et al. [66] reported that the survivability of porcine reproductive and respiratory syndrome virus in pig slurry at $4{ }^{\circ} \mathrm{C}$ and $\mathrm{pH}=7.0$ was 14 days. Parasite eggs and oocysts can survive in pig slurry from a few days up to several years. The most dangerous are highly resistant to inactivation eggs of Ascaris suum [12, 64, 69]. According to the literature [4] Ascaris suum eggs at the temperature of $8{ }^{\circ} \mathrm{C}$ maintain the vitality in pig slurry for 85 days, and mature proglottids of Taenia solium for 76 days. However, Katakam et al. [69] demonstrated that in pig slurry stored for 308 days under laboratory conditions at $5{ }^{\circ} \mathrm{C} 42 \%$ of Ascaris suum eggs were still viable, whereas at $25{ }^{\circ} \mathrm{C}$ all eggs lost their viability within this period of time. In turn, Olszewska et al. [12] noted that in pig slurry stored for 44 weeks (the same time as in Katakam's research) under laboratory conditions at $4{ }^{\circ} \mathrm{C}$ the percentage of invasive eggs of Ascaris suum decreased to a level of $49 \%$, while in pig slurry stored at $20{ }^{\circ} \mathrm{C}$ to $11 \%$. The study of Kachnic et al. [65] also showed that at higher temperatures devitalization of Ascaris suum eggs was increased, however, even after 115 days of raw slurry storage at $42{ }^{\circ} \mathrm{C}$, complete devitalization was not achieved. 
Survival of selected viruses of pigs in slurry $[59,60]$

\begin{tabular}{|c|c|}
\hline Pig virus & Survival in slurry \\
\hline Aujeszky's disease virus (ADV) & 1 day-15 weeks \\
\hline Classical swine fever virus (CSFV) & $14-42$ days \\
\hline African swine fever virus (ASFV) & $60-160$ days \\
\hline Porcine reproductive and respiratory syndrome virus (PRRSV) & 1 day-2 weeks \\
\hline Swine influenza virus (SIV) & $2-9$ weeks \\
\hline Foot-and-mouth disease virus (FMDV) & $2-14$ weeks \\
\hline Porcine parvovirus (PPV) & $14-40$ weeks \\
\hline Porcine rotavirus & 4 months \\
\hline
\end{tabular}

An excessive fertilizing use of pig slurry in fields and pastures or the application of slurry from sick animals, including asymptomatic ones, can be a source of microbial contamination of soils (due to the impairment of self-purifying ability) and plants, which in turn poses a risk of pathogens infiltrating into the food chain of animals (domestic and wild) and humans $[62,64,71]$. Within a short period after the application of slurry on farmland, fecal microorganisms can multiply in the soil, but in the end they are partially or completely eliminated from the soil environment. The pace of death of fecal bacteria in the soil environment is varied and depends primarily on temperature, reaction, type and humidity of the soil, the season and the presence of antagonistic microflora in relation to pathogens. The survival time of the bacteria (Table 2) can range from several days to even a few years, and longer viability is often associated with cold and moist soils; in cold soil $\left(4-6{ }^{\circ} \mathrm{C}\right)$, most pathogens can survive for at least a month $[4,63,71,72]$. The viruses introduced into the soil with pig slurry do not undergo inactivation for a long time, for example the Aujeszky's disease virus maintains infectivity for about 5-6 weeks [60]. In turn, the eggs of Ascaris can be invasive in the soil for several years, while their presence on plants was observed for several months [4]. The survivability of pig pathogens in soils is quite often studied under controlled laboratory conditions. Olszewska et al. [12] demonstrated that the percentage of invasive Ascaris suum eggs in humus layers of podsolic soil, black earth and browned black earth stored for 44 weeks under laboratory conditions at $4{ }^{\circ} \mathrm{C}$ amounted to 59,35 and $43 \%$, respectively, while at $20{ }^{\circ} \mathrm{C}-7,5$ and $4 \%$, respectively.

Grazing animals on grassland abundantly sprinkled with pig slurry or just after spilling slurry on them, or using crops derived from such areas as fodder can cause infection of the animals, increase their helminthiasis and even the death of livestock. There is also a risk of infecting people, especially when sprouts and vegetables intended for direct consumption (e.g. root vegetables such as radishes and carrots or leafy vegetables like lettuce) are grown on land fertilized with pig slurry as well as in the case of eating or processing (for example making unpasteurized apple cider) - without any treatment - of fruit that fell on the soil freshly sprinkled with the slurry [24, 71, 72].

An additional danger is the possibility of contamination of groundwater and surface waters [24, 63, 71-73]. As a result of heavy rain, the microorganisms transferred together with the slurry into the soil can run off to the waters and cause their pollution [24, 63, 71-73]. The survivability of pathogens in water is relatively long and can last many days (Table 4). It is recognized that Salmonella species, which cause one of the most common forms of food poisoning worldwide, can survive for a significant period of time in natural water bodies [72]. According to literature [72], in warm water (20-30 $\left.{ }^{\circ} \mathrm{C}\right)$, Salmonella 
species have the longest survival time, while in cold water $\left(4-8^{\circ} \mathrm{C}\right)$, Yersinia enterocolitica survives best. The use of water containing pathogens from pig slurry to water animals, to irrigate crops or as drinking water poses a threat to human and animal health $[24,63,71,73]$.

Survival of selected pathogens of pigs in water [59, 63]

Table 4

\begin{tabular}{|c|c|}
\hline Pig pathogen & Survival in water \\
\hline Salmonella spp. & $35-147$ days \\
\hline Enteropathogenic Escherichia coli & 90 days \\
\hline Listeria & $7-56$ days \\
\hline Yersinia enterocolitica & $6-448$ days \\
\hline Streptococcus suis & $10-60$ minutes \\
\hline Pasteurella multocida & $1-14$ days \\
\hline Aujeszky's disease virus & $2-7$ days \\
\hline Porcine reproductive and respiratory syndrome virus & $9-11$ days \\
\hline
\end{tabular}

Due to the possibility of posing a threat to human and animal health it is extremely important to properly prepare pig slurry for its agricultural use. Among the known methods of slurry hygienization which lead to the reduction of the number of microbes, the most widely used are: anaerobic digestion, biological treatment of slurry by activated sludge method, composting and aeration [24, 62, 74, 75]. Cote et al. [76] stated that the psychrophilic anaerobic digestion of pig slurry conducted in sequencing batch reactor at $20{ }^{\circ} \mathrm{C}$ for 20 days reduced the indigenous populations of total coliforms and E. coli by 97.94-100 \% and 99.67-100\%, respectively. Moreover, the applied process resulted in the removal of the indigenous populations of Salmonella, Cryptosporidium and Giardia. Paluszak et al. [77] demonstrated that the process of anaerobic digestion of pig slurry carried out in thermophilic conditions within the temperature range $49-51.5{ }^{\circ} \mathrm{C}$ guarantees obtaining a microbiologically safe product. As a result of the conducted studies it was established that the complete elimination of Ascaris suum eggs takes about 4 hours, whereas the theoretical time of full inactivation of Salmonella Senftenberg exceeds 12 hours. Bauza-Kaszewska et al. [78] proved that aeration of pig slurry in the mesophilic variant (the initial temperature of the process amounted to $35^{\circ} \mathrm{C}$ ) leads to the effective elimination of pathogens - the theoretical survival time of Salmonella Typhimurium, Salmonella Senftenberg $\mathrm{W}_{775}$ and enterococci in the aerated slurry ranged from 13 to 25 days.

An efficient method of pig slurry sanitization, especially in the case of infectious diseases in animals, is a chemical disinfection with the use of chemical compounds, primarily calcium oxide (quicklime) and calcium hydroxide (slaked or hydrated lime). The addition of calcium compounds, apart from a hygienization activity (due to slurry alkalization and temperature increase resulting from a rapid exothermic reaction of lime with water), reduces the emission of odour from the slurry. Furthermore, a mixture of pig slurry with lime is a valuable fertilizer enhancing the fertility of acid soils which require regular lime application [24, 74, 75]. Heinonen-Tanski et al. [79] used hydrated lime and commercial chemical product Nordkalk Velox (a limestone-based product containing oxygen and calcium peroxide) to destroy enteric microorganisms contained in pig slurry. The researchers found that both chemicals (applied at a dose of $30 \mathrm{~g} / \mathrm{dm}^{3}$ ) reduced all coliforms to the level below the detection limit in one or two days of treatment. However, 
in the reduction of coliphages and enterococci, Velox proved to be slightly more effective [79]. Turner and Williams [80] evaluated chemical treatment with the use of granular $\mathrm{NaOH}$ or powdered $\mathrm{Ca}(\mathrm{OH})_{2}$ for the inactivation of African swine fever virus and swine vesicular disease virus (SVDV) in pig slurry. The results showed that the addition of either chemical to pig slurry caused rapid (within 150 s) inactivation of ASFV at $4{ }^{\circ} \mathrm{C}$ (the addition of $\mathrm{NaOH}$ or $\mathrm{Ca}(\mathrm{OH})_{2}$ was $1 \%(\mathrm{w} / \mathrm{v})$ ) and SVDV at $4{ }^{\circ} \mathrm{C}$ as well as at $22{ }^{\circ} \mathrm{C}$ (the addition of $\mathrm{NaOH}$ or $\mathrm{Ca}(\mathrm{OH})_{2}$ was $1.5 \%$ (w/v)) [80]. The effect of alkaline treatment of pig slurry using hydrated lime on the survival of porcine epidemic diarrhea virus (PEDV) was investigated by Stevens et al. [81]. The researchers stated that the addition of $\mathrm{Ca}(\mathrm{OH})_{2}$ that increased the slurry $\mathrm{pH}$ to 10 or higher inactivated PEDV. However, with higher $\mathrm{pH}$ of the slurry, increased ammonia emissions may occur [81].

\section{Contamination of soil, water and plants with antibiotics and their metabolites}

A major issue is also the presence of hormones, antibiotics and their residues as well as other veterinary medicines in pig slurry. Until 2005 in the European Union countries antibiotic growth promoters (AGP) were commonly used in pig production; their addition to feeds improves the increase of animal body weight and the degree of food intake as well as supports the prevention of diseases that cause the greatest loss during breeding. The extensive and unjustifiable use of antibiotics led to the formation of dangerous, antibiotic-resistant strains of microorganisms transmitted with the excreta into the environment, being then a source of drug resistance genes transferred to other microorganisms present in the soil $[24,71,82,83]$. Because of the escalation of antibiotic-resistance bacteria phenomenon the Council of the European Union introduced on 1 January 1999 the prohibition of applying in livestock farming antibiotics (administered as AGP) used in human medicine [84], while from 1 January 2006 under the Regulation (EC) No 1831/2003 of the European Parliament and of the Council of 22 September 2003 the application of antibiotic growth promoters as feed additives was forbidden [85]. Unfortunately, in many countries (China, Japan, Brazil, Australia, Ukraine) the use of antibiotic growth promoters on livestock is not prohibited [82].

Currently, in the European Union countries antibiotics in pig production can be used in two manners: therapeutically to treat specific diseases and metaphylactically to eliminate or reduce, as early as possible, an infectious agent so that it cannot cause disease [24, 71, 83, 86]. The use of antibiotics requires a veterinary diagnosis and prescription and must be done under veterinary guidance. Nevertheless, there is a risk of their excessive or inadequate dosage or illegal use of antibiotic growth promoters [82, 83]. These drugs are not completely metabolized by animals and, therefore, their residues are excreted in urine and faeces in an unaltered form that is still active. Up to $90 \%$ of some veterinary antibiotics can be excreted as the parent compound and its conjugates, oxidation or hydrolysis products [87-89]. Hormones and antibiotic residues present in pig slurry spread on farmland may accumulate in the soil and plant tissues as well as penetrate into the groundwater and surface waters as a result of leaching or surface runoff [71, 90-92]. Tetracyclines and sulfonamides are the most commonly used antibiotics in pig breeding. The presence of residues of these antibiotics in pig slurry, groundwater and surface water around large-scale livestock farms as well as in soils fertilized with slurry from various 
countries (European Union countries, China, USA) has been widely reported $[7,23,86,93]$.

In European countries, the maximum detected concentration of chlortetracycline in pig slurry was $46.0 \mathrm{mg} / \mathrm{kg}$ in Austria [90], $24.4 \mathrm{mg} / \mathrm{kg}$ in Denmark [94] and $4.0 \mathrm{mg} / \mathrm{kg}$ in Spain [95]. In China, the highest reported concentration of chlortetracycline in pig slurry was $764.4 \mathrm{mg} / \mathrm{kg}$ [96]. As representatives of the sulfonamides group, sulfamethazine was detected in pig slurry with concentration levels up to $20.0 \mathrm{mg} / \mathrm{kg}$ in Austria [90] and up to $28.7 \mathrm{mg} / \mathrm{kg}$ in China [96]. The application of antibiotics containing pig slurry as fertilizer is one of the pathways for antibiotic residues release into the environment. It was reported that the concentration of antibiotics in soils from different regions varied significantly. In the sandy soil samples from Germany the highest average concentration of chlortetracycline was $198.7 \mu \mathrm{g} / \mathrm{kg}$ [97]; in the loamy sand and sandy soil samples from Denmark the maximum concentration of chlortetracycline was 15.5 and $11.7 \mu \mathrm{g} / \mathrm{kg}$, respectively [98]; and in the soil samples from organic vegetable bases in China the maximum concentration of chlortetracycline was $1079 \mu \mathrm{g} / \mathrm{kg}$ [23]. Compounds belonging to the sulfonamides group were also detected in soil samples. Sulfamethazine at the concentration range of $34.5-663 \mathrm{ng} / \mathrm{kg}$ was determined in soil samples (top soil, 0-15 cm) from the USA [99], while sulfadoxine at the concentration range of $1200-9100 \mathrm{ng} / \mathrm{kg}$ in soil samples from organic vegetable bases in China [23].

From the soil fertilized with pig slurry, antibiotics may be transported to the aquatic environment; to ditches, streams, rivers, ponds and lakes through runoff and drain flow as well as to groundwater by leaching [7, 88, 100]. Numerous literature data [7, 23, 88, 93, 99] report the presence of antibiotics in surface and groundwater samples collected in the vicinity of pig farms. In river water samples from Jiangsu province (China) Wei at al. [88] found chlortetracycline and sulfadoxine at concentration of up to 1490 and $340 \mathrm{ng} / \mathrm{dm}^{3}$, respectively. Shelver et al. [99] detected sulfamethoxazole in surface and groundwater samples from the USA at concentration of 43 and $20.5 \mathrm{ng} / \mathrm{dm}^{3}$, respectively. Studies by Campagnolo et al. [7] showed that the concentration of chlortetracycline and sulfamethazine in water samples from field tile lines (USA) was 2000 and $300 \mathrm{ng} / \mathrm{dm}^{3}$, respectively. $\mathrm{Hu}$ et al. [23] reported that sulfamethoxazole could be measured in groundwater samples collected from northern China, with concentration ranging from 7.2 to $9.5 \mathrm{ng} / \mathrm{dm}^{3}$.

Previous studies [23, 87, 95] also indicate that crops from the fields treated with pig slurry can accumulate antibiotics. Conde-Cid et al. [95] detected chlortetracycline and sulfamethazine in grass and corn grown on soils amended with pig slurry at level of $100 \mu \mathrm{g} / \mathrm{kg}$. Grote at al. [87] demonstrated that roots of growing wheat contained up to $1104 \mu \mathrm{g} / \mathrm{kg}$ of chlortetracycline and up to $487 \mu \mathrm{g} / \mathrm{kg}$ of sulfadiazine, while leaves and stems contained up to $822 \mu \mathrm{g} / \mathrm{kg}$ of chlortetracycline and up to $44 \mu \mathrm{g} / \mathrm{kg}$ of sulfadiazine. Hu et al. [23] revealed that the concentration of antibiotics in vegetables from the organic vegetable bases was higher than that from ordinary vegetables as well as that the concentration of antibiotics in various tissues of vegetables was different. The concentration of chlortetracycline in roots and leaves of coriander was in the range of $92-481 \mu \mathrm{g} / \mathrm{kg}$ and $54-532 \mu \mathrm{g} / \mathrm{kg}$, respectively; in stems and leaves of radish was 9.4 and $6.0-8.0 \mu \mathrm{g} / \mathrm{kg}$ respectively; in leaves of celery amounted to $12.6 \mu \mathrm{g} / \mathrm{kg}$ and in leaves of rapeseed was at level of $3.3 \mu \mathrm{g} / \mathrm{kg}$. No chlortetracycline was detected in radish roots, rapeseed roots and celery stems. From the sulfonamides group, sulfadoxine was determined in all tissues of the examined plants. The concentration of sulfadoxine in roots, stems and leaves of radish was 
in the range of $0.1-0.4 \mu \mathrm{g} / \mathrm{kg}, 0.2-0.5 \mu \mathrm{g} / \mathrm{kg}$ and $0.2-0.6 \mu \mathrm{g} / \mathrm{kg}$, respectively; in roots and leaves of rapeseed ranged from 0.1 to $0.5 \mu \mathrm{g} / \mathrm{kg}$ and from 0.3 to $1.2 \mu \mathrm{g} / \mathrm{kg}$, respectively; in stems and leaves of celery was in the range of $0.1-0.3 \mu \mathrm{g} / \mathrm{kg}$ and $0.2-0.6 \mu \mathrm{g} / \mathrm{kg}$, respectively and in roots and leaves of coriander ranged from 0.1 to $0.5 \mu \mathrm{g} / \mathrm{kg}$ and from 0.2 to $1.0 \mu \mathrm{g} / \mathrm{kg}$, respectively [23].

The presence of veterinary antibiotics in the soil-water environment causes changes in the composition and functioning (e.g. nutrient cycling and pollutant degradation) of the soil microorganisms and increased occurrence of antibiotic resistant genes in various bacteria [87, 89, 101]. Moreover, the residues of antibiotics have the potential to accumulate in crops which may negatively affect human and animal health (possible development of allergies and antibiotics resistance in humans and animals) [95]. In order to avoid contamination of the environment with antibiotics derived from pig slurry, it is necessary to eliminate the abuse of antibiotics in animal husbandry and reduce the concentration of antibiotic residues in the slurry [89]. Different treatment techniques like anaerobic digestion [101-103], aeration [104], electron beam irradiation [105] and sorption [89] lead to the partial or almost complete elimination of antibiotics from pig slurry. Feng et al. [101] investigated removal of the antibiotics during anaerobic digestion of pig slurry at thermophilic and psychrophilic conditions. The results showed that removal of sulfamethaxazole and erythromycin was close to $100 \%$, however, no removal was found for sulfadiazine and sulfamethizole. The researchers also stated that the presence of antibiotics in pig slurry does not adversely affect on biogas yield [101]. Alvarez et al. [103] studied the removal and effect of oxytetracycline and chlortetracycline on methane production during anaerobic digestion of pig slurry. They found that both antibiotics were removed quite quickly and almost completely at $35{ }^{\circ} \mathrm{C}$ and $\mathrm{pH}=7$, however, both compounds caused reduction in methane production [103]. Masse et al. [106] also noticed that presence of some antibiotics (penicillin and tetracycline) in pig slurry had an inhibitory effect on methane production. Seo et al. [104] investigated the effect of aeration on degradation of tetracycline and tylosin during storage of pig slurry. The results showed that applied treatment enhanced the degradation of antibiotics in pig slurry [104]. Another effective method of removing antibiotics from pig slurry is the electron beam irradiation technology. Chung et al. [105] established that the degradation efficiency of ampicillin in pig slurry was around $98 \%$ at an absorbed dose of $10 \mathrm{kGy}$. Ngigi et al. [89] tested the use of five different biochars to enhance sorption of antibiotics (sulfamethazine, oxytetracycline, florfenicol, ciprofloxacin) in pig slurry. The results showed that the addition of $2 \%$ of biochar from pine cone was sufficient for an increased immobilization of florfenicol and sulfamethazine [89].

\section{Conclusions}

Pig slurry contains large amounts of organic matter and easily assimilable nutrients for plants, therefore using it as a natural fertilizer brings measurable effects like improving the quality and yield of crops as well as beneficially influencing the soil. However, in areas where intensive pig farming is carried out, there are problems with the proper management of large quantities of slurry, which sometimes results in its spreading in doses exceeding the permissible levels. The use of excessive quantities of slurry, especially when it has not undergone any hygienization processes, and the improper storage involve a risk of 
contamination the water-soil environment with biogenic elements, heavy metals, pharmaceuticals and pathogenic microorganisms.

Nitrogen and phosphorus, in addition to the fact that they play a major role in crop production, are responsible for the degradation of the water-soil environment. Excessive nitrogen and phosphorus deposition in the soil leads to its over-fertilization and, as a consequence, to lowering the crop yield. Phosphorus compounds present in surface waters contribute to their eutrophication, whereas nitrogen compounds present in groundwater affect the quality of drinking water and their high concentration is detrimental to both humans and animals. In turn, an excessive concentration of zinc and copper in the soil can be a source of contamination of plants and groundwater, and therefore these elements may be incorporated into the food chain. In order to reduce the emission of biogenic elements and heavy metals to the water-soil environment, the doses and dates of slurry application should be respected, and the amount of nitrogen, phosphorus, copper and zinc in excreted faeces should be reduced, which can be achieved through proper feeding of pigs (use of the addition of phytase and amino acid chelates, high quality protein, well balanced fodder as well as low protein diet).

The presence of potentially pathogenic microflora and antibiotics in pig slurry is also a significant hazard to the environment. Fertilization with slurry containing pathogenic and antibiotic-resistant microorganisms may cause microbial contamination of soils, groundwater, surface waters and plants, which in turn poses a threat of spreading zoonoses and epizootic diseases as a result of pathogens entering the food chain of animals and humans. To reduce the possibility of soil and water contamination with pathogenic microorganisms, the slurry should be treated appropriately. The most effective methods for the inactivation of microbes in pig slurry include anaerobic digestion, aeration and chemical treatment with calcium compounds. In turn, agricultural use of pig slurry in which veterinary medicines and their metabolites are present may lead to changes in the composition and functioning of the soil microorganisms and increased occurrence of antibiotic-resistant bacteria. Furthermore, antibiotics may penetrate into the groundwater and surface waters as well as accumulate in plant tissues which may contribute to the development of allergies and antibiotics resistance in humans and animals. An efficient way to avoid contamination of the environment with veterinary medicines derived from pig slurry is the use of antibiotics in pig breeding only when it is necessary (veterinary diagnosis) and their elimination from the slurry using processes such as anaerobic digestion or aeration.

\section{References}

[1] OECD/FAO. OECD-FAO Agricultural Outlook 2018-2027. OECD Publishing, Paris/FAO, Rome 2018. DOI: 10.1787/agr_outlook-2018-en.

[2] Watabe M, Rao JR, Stewart TA, Xu J, Millar BC, Xiao L, et al. Lett Appl Microbiol. 2003;36(4):208-212. DOI: 10.1046/j.1472-765X.2003.01293.x.

[3] Marszałek M, Kowalski Z, Makara A. Ecol Chem Eng S. 2018;25(3):383-394. DOI: 10.1515/eces-2018-0026.

[4] Marszałek M, Kowalski Z, Makara A. Technical Trans Chem. 2014;111:81-91. http://suw.biblos.pk.edu.pl/resourceDetailsRPK\&rId=49219.

[5] Sanchez M, Gonzalez JL. Bioresour Technol. 2005;96:1117-1123. DOI: 10.1016/j.biortech.2004.10.002.

[6] Strauch D. Rev Sci Tech OIE. 1991;10(3):813-846. DOI: 10.20506/rst.10.3.565.

[7] Campagnolo ER, Johnson KR, Karpati A, Rubin CS, Kolpin DW, Meyer MT, et al. Sci Total Environ. 2002;299:89-95. DOI: 10.1016/S0048-9697(02)00233-4. 
[8] Moral R, Perez-Murcia MD, Perez-Espinosa A, Moreno-Caselles J, Paredes C. Waste Manage. 2005;25:719-725. DOI: 10.1016/j.wasman.2004.09.010.

[9] Loughrin JH, Szogi AA, Vanotti MB. Appl Eng Agric. 2006;22:867-873. DOI: 10.13031/2013.22258.

[10] Masse L, Massé DI. Bioresour Technol. 2010;101:6304-6308. DOI: 10.1016/j.biortech.2010.03.037.

[11] Kwiecińska A, Konieczny K. Ecol Chem Eng A. 2013;20(2):239-249. DOI: 10.2428/ecea.2013.20(02)024.

[12] Olszewska H, Skowron K, Skowron KJ, Kaczmarek A. Helminthologia. 2014;51(3):203-209. DOI: 10.2478/s11687-014-0230-y.

[13] Riaño B, García-González MC. J Environ Manage. 2014;132:87-93. DOI: 10.1016/j.jenvman.2013.10.014.

[14] Fragoso RA, Duarte EA, Paiva J. Water Air Soil Pollut. 2015;226:131. DOI: 10.1007/s11270-015-2388-4.

[15] Antezana W, De Blas C, García-Rebollar P, Rodríguez C, Beccaccia A, Ferrer P, et al. Nutr Cycl Agroecosyst. 2016;104:159-173. DOI: 10.1007/s10705-016-9764-3.

[16] Gaj R, Budka A, Antonkiewicz J, Bąk K, Izychard P. Soil Sci Ann. 2018;69(3):194-204. DOI: 10.2478/ssa-2018-0020.

[17] Ustawa z dnia 10 lipca 2007 r. o nawozach i nawożeniu. Dz.U. 2007, Nr 147, poz. 1033. (Polish Act of 10 July 2007 on fertilizers and fertilization. J Laws 2007, No. 147, item 1033). http://prawo.sejm.gov.pl/isap.nsf/DocDetails.xsp?id=WDU20180001259.

[18] Loyon L. Waste Manage. 2017;61:516-520. DOI: 10.1016/j.wasman.2016.11.040.

[19] Obwieszczenie Ministra Rolnictwa i Rozwoju Wsi z dnia 17 lutego 2014 r. w sprawie ogłoszenia jednolitego tekstu rozporządzenia Ministra Rolnictwa i Rozwoju Wsi w sprawie szczegółowego sposobu stosowania nawozów oraz prowadzenia szkoleń z zakresu ich stosowania. Dz.U. 2014, poz. 393. (Public Notice of Minister of Agriculture and Rural Development of 17 February 2014 on consolidated text of the Regulation of the Minister of Agriculture and Rural Development on the detailed method of fertilizers application and conducting training in their use. J Laws Republic of Poland 2014, item 393). http://prawo.sejm.gov.pl/isap.nsf/DocDetails.xsp?id=WDU20140000393.

[20] Council Directive 91/676/EEC of 12 December 1991 concerning the protection of waters against pollution caused by nitrates from agricultural sources. Official J Europ Communities L 375. 31.12.1991. https://eurlex.europa.eu/legal-content/en/ALL/?uri=CELEX:31991L0676.

[21] Szostak B. Ecol Chem Eng A. 2012;19(1-2):25-33. DOI: 10.2428/ecea.2012.19(01)002.

[22] Mantovi P, Bonazzi G, Maestri E, Marmiroli N. Plant Soil. 2003;250:249-257. DOI: 10.1023/A:1022848131043.

[23] Hu X, Zhou Q, Luo Y. Environ Pollut. 2010;158:2992-2998. DOI: 10.1016/j.envpol.2010.05.023.

[24] Skowron K, Bauza-Kaszewska J, Kaczmarek A, Budzyńska A, Gospodarek E. Post. Mikrobiol. 2015;54(3):235-249. http://pm.microbiology.pl/web/archiwum/vol5432015235.pdf.

[25] Best Available Techniques (BAT) Reference Document for the Intensive Rearing of Poultry or Pigs. Industrial Emissions Directive 2010/75/EU (Integrated Pollution Prevention and Control). Luxembourg: Publications Office of the European Union; 2017. DOI: 10.2760/020485.

[26] Kornegay ET, Harper AF. The Professional Animal Scientist. 1997;13:99-111. DOI: 10.15232/S1080-7446(15)31861-1.

[27] Set of Recommendations for Good Agricultural Practice. Warszawa: Ministry of Agriculture and Rural Development, Ministry of Maritime Economy and Inland Navigation; 2019. https://www.gov.pl/documents/912055/913531/0362_za\%C5\%82_do_pisma_ZBI\%C3\%93R_ZALECE\%C 5\%83_DOBREJ_PRAKTYKI_ROLNICZEJ_26022019_egz_BIP.pdf.

[28] Dourmad JY, Garcia-Launay F, Narcy A. Pig nutrition: impact on nitrogen, phosphorus, $\mathrm{Cu}$ and $\mathrm{Zn}$ in pig manure and on emissions of ammonia, greenhouse gas and odours. Batfarm European Workshop Reconciling Livestock Management to the Environment. Mar 2013. Rennes, France. https://hal.archives-ouvertes.fr/hal-01594359/document.

[29] Lu L, Liao X, Luo X. J Integr Agr. 2017;16(12):2815-2833. DOI: 10.1016/S2095-3119(17)61701-5.

[30] Oster M, Gerlinger C, Heide K, Just F, Borgelt L, Wolf P, et al. Ambio. 2018;47(Suppl. 1):S20-S29. DOI: 10.1007/s13280-017-0969-8.

[31] Gupta RK, Gangoliya SS, Singh NK. J Food Sci Technol. 2015;52(2):676-684. DOI: 10.1007/s13197-013-0978-y.

[32] Lemanowicz J, Koper J. Ecol Chem Eng A. 2012;19(11):1349-1355. DOI: 10.2428/ecea.2012.19(11)129.

[33] Mantovi P, Fumagalli L, Beretta GP, Guermandi M. J Hydrol. 2006;316:195-212. DOI: 10.1016/j.jhydrol.2005.04.026.

[34] Sahoo PK, Kim K, Powell MA. Curr Pollution Rep. 2016;2:178-187. DOI: 10.1007/s40726-016-0033-5.

[35] Ward MH, Jones RR, Brender JD, de Kok TM, Weyer PJ, Nolan BT, et al. Int J Environ Res Public Health. 2018;15:1-31. DOI: 10.3390/ijerph15071557.

[36] Zhai Y, Zhao X, Teng Y, Li X, Zhang J, Wu J, et al. Ecotox Environ Safety. 2017;137:130-142. DOI: 10.1016/j.ecoenv.2016.11.010. 
[37] Costagliola A, Roperto F, Benedetto B, Anastasio A, Marrone R, Perillo A, et al. Environ Sci Pollut Res. 2014;21:6252-6257. DOI: 10.1007/s11356-014-2520-9.

[38] Sidhu PK, Mahajan V, Verma S, Ashuma, Gupta MP. Toxicol Int. 2014;21(2):186-190. DOI: 10.4103/0971-6580.139806.

[39] Wang Y, Zhou J, Wang G, Cai S, Zeng X, Qiao S. J Anim Sci Biotechnol. 2018; 9:60.DOI: 10.1186/s40104-018-0276-7.

[40] Zouaoui M, Létourneau-Montminy MP, Guay F. Anim Feed Sci Technol. 2018;238:18-28. DOI: 10.1016/j.anifeedsci.2018.01.019.

[41] Grela ER, Matras J, Czech A. Czech J. Anim Sci. 2011;56:443-450. DOI: 10.17221/3237-CJAS.

[42] Dourmad JY, Jondreville C. Livest Sci. 2007;112:192-198. DOI: 10.1016/j.livsci.2007.09.002.

[43] Obwieszczenie Ministra Rolnictwa i Rozwoju Wsi z dnia 1 sierpnia 2013 r. w sprawie ogłoszenia jednolitego tekstu rozporządzenia Ministra Rolnictwa i Gospodarki Żywnościowej w sprawie warunków technicznych, jakim powinny odpowiadać budowle rolnicze i ich usytuowanie. Dz.U. 2014, poz. 81. (Public Notice of Minister of Agriculture and Rural Development of 1 August 2013 on consolidated text of the Regulation of the Minister of Agriculture and Food Economy on the technical conditions for agricultural facilities and their location. Journal of Laws of the Republic of Poland from 2014, item 81). http://prawo.sejm.gov.pl/isap.nsf/DocDetails.xsp?id=WDU20140000081.

[44] Ulén B, Pietrzak S, Tonderski KS, editors. Self-evaluation of farms for improved nutrient management and minimised environmental impacts. Falenty: Publishing House of the Institute of Technology and Life Sciences in Falenty; 2013. http://balticsea2020.org/english/images/Bilagor/2014\%20Guide\%20-\%20Selfevaluation $\% 20$ of $\% 20$ farms.pdf.

[45] Feng Z, Zhu H, Deng Q, He Y, Li J, Yin J, et al. Environ Earth Sci. 2018;77:103. DOI: 10.1007/s12665-018-7300-2.

[46] Jensen J, Larsen MM, Bak J. Environ Pollut. 2016;214:334-340. DOI: 10.1016/j.envpol.2016.03.034.

[47] Commission Regulation (EC) No 1334/2003 of 25 July 2003 amending the conditions for authorisation of a number of additives in feedingstuffs belonging to the group of trace elements. Official J Europ Communities L 187. 26.7.2003. https://eur-lex.europa.eu/legal-content/EN/TXT/ ?uri=CELEX\%3A32003R1334.

[48] Commission Regulation (EC) No 639/1999 of 25 March 1999 concerning the authorisation of a new additive in feedingstuffs. Official J Europ Communities L 82. 26.3.1999. https://eur-lex.europa.eu/ legal-content/EN/TXT/?uri=CELEX\%3A31999R0639.

[49] De la Torre AI, Jimenez JA, Carballo M, Fernandez C, Roset J, Munoz MJ. Chemosphere. 2000;41:1629-1635. DOI: 10.1016/S0045-6535(00)00038-2.

[50] Martinez J, Peu P. Soil Use Manage. 2000;16:100-1007. DOI: 10.1111/j.1475-2743.2000.tb00183.x.

[51] Lipoth SL, Schoenau JJ. J Plant Nutr Soil Sci. 2007;170:378-386. DOI: 10.1002/jpln.200625007.

[52] Nicholson FA, Smith SR, Alloway BJ, Carlton-Smith C, Chambers BJ. Sci Total Environ. 2003;311:205-219. DOI: 10.1016/S0048-9697(03)00139-6.

[53] Luo L, Ma Y, Zhang S, Wei D, Zhu YG. J Environ Manage. 2009;90(8):2524-2530. DOI: 10.1016/j.jenvman.2009.01.011.

[54] Legros S, Doelsch E, Feder F, Moussard G, Sansoulet J, Gaudet JP, et al. Agr Ecosyst Environ. 2013;164:70-79. DOI: 10.1016/j.agee.2012.09.008.

[55] De Conti L, Ceretta CA, Ferreira PAA, Lourenzi CR, Girotto E, Lorensini F, et al. Agr Ecosyst Environ. 2016;216:374-386. DOI: 10.1016/j.agee.2015.09.040.

[56] L'Herroux L, Roux SL, Appriou P, Martinez J. Environ Pollut. 1997;97(1-2):119-130. DOI: 10.1016/S0269-7491(97)00072-9.

[57] Girotto E, Ceretta CA, Rossato LV, Farias JG, Tiecher TL, De Conti L, et al. Ecotoxicol Environ Safety. 2013;93:145-55. DOI: 10.1016/j.ecoenv.2013.03.021.

[58] Berenguer P, Cela S, Santiveri F, Boixadera J, Lloveras J. Agron J. 2008;100:1056-1061. DOI: 10.2134/agronj2007.0321.

[59] Pejsak Z. Ochrona zdrowia świń (Health protection of pigs). Poznań: Polskie Wydawnictwo Rolnicze; 2007. ISBN: 9788391790076.

[60] Zimmerman JJ, Karriker LA, Ramirez A, Schwartz KJ, Stevenson GW. Diseases of Swine. 10th Edition. John Wiley Sons, Inc; 2012. ISBN: 9780813822679.

[61] Bornay-Llinares FJ, Navarro-i-Martínez L, García-Orenes F, Araez H, Pérez-Murcia MD, Moral R. Livest Sci. 2006;102:237-242. DOI: 10.1016/j.livsci.2006.03.023.

[62] Martens W, Böhm R. Bioresour Technol. 2009;100:(22):5374-5378. DOI: 10.1016/j.biortech.2009.01.014.

[63] Ziemer CJ, Bonner JM, Cole D, Vinjé J, Constantini V, Goyal S, et al. J Anim Sci. 2010;88(13 Suppl):E84-E94. DOI: 10.2527/jas.2009-2331. 
[64] Olszewska H, Skowron K. J Central Europ Agricult. 2013;14(2):847-853. DOI: 10.5513/JCEA01/14.2.1275.

[65] Kachnič J, Sasáková N, Papajová I, Veszelits Laktičová K, Hromada R, Harkabus J, et al. Helminthologia. 2013;50(3):147-154. DOI: 10.2478/s11687-013-0124-4.

[66] Ajariyakhajorn C, Goyal SM, Robinson RA, Johnston LJ, Clanton CA. New Microbiol. 1997;20(4):365-369. https://www.ncbi.nlm.nih.gov/pubmed/9385609.

[67] Côté C, Villeneuve A, Lessard L, Quessy S. Livest Sci. 2006;102:204-210. DOI: 10.1016/j.livsci.2006.03.018.

[68] Bøtner A, Belsham GJ. Vet Microbiol. 2012;157:41-49. DOI: 10.1016/j.vetmic.2011.12.010.

[69] Katakam KK, Roepstorff A, Popovic O, Kyvsgaard NC, Thamsborg SM, Dalsgaard A. Parasitology. 2013;140(3):378-384. DOI: 10.1017/S0031182012001722.

[70] Cools D, Merckx R, Vlassak K, Verhegen J. Appl Soil Ecol. 2001;17:53-62. DOI: 10.1016/S0929-1393(00)00133-5.

[71] Venglovsky J, Sasakova N, Placha I. Bioresour Technol. 2009;100:5386-5391. DOI: 10.1016/j.biortech.2009.03.068.

[72] Guan TY, Holley RA. J Environ Qual. 2003;32(2):383-392. DOI: 10.2134/jeq2003.3830.

[73] Gessel PD, Hansen NC, Goyal SM, Johnston LJ, Webb J. Appl Soil Ecol. 2004;25:237-243. DOI: 10.1016/j.apsoil.2003.09.008.

[74] Turner C, Burton CH. Bioresour Technol. 1997;61:9-20. DOI: 10.1016/S0960-8524(97)84693-7.

[75] Heinonen-Tanski H, Mohaibes M, Karinen P, Koivunen J. Livest Sci. 2006;102:248-255. DOI: 10.1016/j.livsci.2006.03.024.

[76] Côté C, Massé DI, Quessy S. Bioresour Technol. 2006;97(4):686-691. DOI: 10.1016/j.biortech.2005.03.024.

[77] Paluszak Z, Skowron K, Bauza-Kaszewska J, Olszewska H, Kroplewska M. Acta Sci Pol. Agricultura 2016;15(4):49-59. http://agricultura.acta.utp.edu.pl/index.php/agricultura/article/view/52.

[78] Bauza-Kaszewska J, Paluszak Z, Olszewska H. Ann Anim Sci. 2015;15(3):737-745. DOI: 10.1515/aoas-2015-0011.

[79] Heinonen-Tanski H, Antola S, Weppling K. Hydrated lime and Velox rapidly reduce enteric micro-organisms of manure. In: Bernal MP, Moral R, Clemente R, Paredes C, editors. Sustainable Organic Waste Management for Environmental Protection and Food Safety. RAMIRAN 2004. FAO and CSIC. 2005;2:33-36. http://ramiran.uvlf.sk/index.php?page=ramiran04.

[80] Turner C, Williams SM. J Appl Microbiol. 1999;87:148-157. DOI: 10.1046/j.1365-2672.1999.00802.x.

[81] Stevens EE, Miller DN, Brittenham BA, Vitosh-Sillman SJ, Brodersen BW, Jin VL, et al. J Swine Health and Prod. 2018;26:95-100. https://www.aasv.org/shap/issues/v26n2/v26n2p95.pdf .

[82] Maron DF, Smith TJ, Nachman K. Global Health. 2013;9:48. DOI: 10.1186/1744-8603-9-48.

[83] Barton MD. Impact of antibiotic use in the swine industry. Curr Opin Microbiol. 2014;19:9-15. DOI: 10.1016/j.mib.2014.05.017.

[84] Council Regulation (EC) No 2821/98 of 17 December 1998 amending, as regards withdrawal of the authorisation of certain antibiotics, Directive 70/524/EEC concerning additives in feedingstuffs. Official J Europ Communities L 351. 29.12.1998. https://eur-lex.europa.eu/legal-content/EN/TXT/ ?uri=celex:31998R2821.

[85] Regulation (EC) No 1831/2003 of the European Parliament and of the Council of 22 September 2003 on additives for use in animal nutrition. Official J Europ Communities L 268. 18.10.2003. https://eur-lex.europa.eu/legal-content/EN/TXT/?uri=CELEX\%3A32003R1831.

[86] Domínguez C, Flores C, Caixach J, Mita L, Piña B, Comas J, et al. Environ Sci Pollut Res. 2014;21:12336-12344. DOI: 10.1007/s11356-014-3174-3.

[87] Grote M, Schwake-Anduschus C, Michel R, Stevens H, Heyser W, Langenkämper G, et al. Landbauforsch Volk. 2007;57:25-32. https://pdfs.semanticscholar.org/c807/c2adddb89a09062a15da82950f218506e18f.pdf.

[88] Wei R, Ge F, Huang S, Chen M, Wang R. Chemosphere. 2011;82:1408-1414. DOI: 10.1016/j.chemosphere.2010.11.067.

[89] Ngigi AN, Ok YS, Thiele-Bruhn S. J Hazard Mater. 2019;364:663-670. DOI: 10.1016/j.jhazmat.2018.10.045.

[90] Martinez-Carballo E, Gonzalez-Barreiro C, Scharf S, Gans O. Environ Pollut. 2007;148:570-579. DOI: 10.1016/j.envpol.2006.11.035.

[91] Pinheiro A, Albano RMR, Alves TC, Kaufmann V, da Silva MR. Agr Water Manage. 2013;129:1-8. DOI: 10.1016/j.agwat.2013.06.019.

[92] Kay P, Blackwell PA, Boxall ABA. Chemosphere. 2005;59(7):951-959. DOI: 10.1016/j.chemosphere.2004.11.055. 
[93] Tong L, Li P, Wang Y, Zhu K. Chemosphere. 2009;74:1090-1097. DOI: 10.1016/j.chemosphere.2008.10.051.

[94] Jacobsen AM, Halling-Sørensen B. Anal Bioanal Chem. 2006;384:1164-1174. DOI: 10.1007/s00216-005-0261-9.

[95] Conde-Cid M, Alvarez-Esmorís C, Paradelo-Núnez R, Novoa-Munoz JC, Arias-Estevez M, Alvarez-Rodríguez E, et al. J Clean Prod. 2018;197:491-500. DOI: 10.1016/j.jclepro.2018.06.217.

[96] Pan X, Qiang Z, Ben W, Chen M. Chemosphere. 2011;84:695-700. DOI: 10.1016/j.chemosphere.2011.03.022.

[97] Hamscher G, Sczesny S, Höper H, Nau H. Anal Chem. 2002;74(7):1509-1518. DOI: 10.1021/ac015588m.

[98] Jacobsen AM, Halling-Sørensen B, Ingerslev F, Hansen SH. J Chromatogr A. 2004;1038:157-170. DOI: 10.1016/j.chroma.2004.03.034.

[99] Shelver W, Hakk H, Larsen GL, DeSutter TM, Casey FXM. J Chromatogr A. 2010;1217:1273-1282. DOI: 10.1016/j.chroma.2009.12.034.

[100] Szymonik A, Lach J, Malińska K. Ecol Chem Eng S. 2017;24(1):65-85. DOI: 10.1515/eces-2017-0006.

[101] Feng L, Casas ME, Ottosen LDM, Møller HB, Bester K. Sci Total Environ. 2017;603-604:219-225. DOI: 10.1016/j.scitotenv.2017.05.280.

[102] Panseri S, D'Imporzano G, Pognani M, Cavalli M, Chiesa L, Adani F. Int Biodeter Biodegr. 2013;85:205-209. DOI: 10.1016/j.ibiod.2013.07.010.

[103] Álvarez JA, Otero L, Lema JM, Omil F. Bioresour Technol. 2010;101:8581-8586. DOI: 10.1016/j.biortech.2010.06.075.

[104] Seo Y, Lim S, Choi S, Heo S, Yoon B, Park Y, et al. Korean J Soil Sci Fert. 2018;51(1):8-15. DOI: 10.7745/KJSSF.2018.51.1.008.

[105] Chung BY, Kim JS, Lee MH, Lee KS, Hwang SA, Cho JY. Radiat Phys Chem. 2009;78:711-713. DOI: 10.1016/j.radphyschem.2009.03.051.

[106] Massé DI, Lu D, Masse L, Droste RL. Bioresour Technol. 2000;75:205-211. DOI: 10.1016/S0960-8524(00)00046-8. 